\title{
Impact of Customer Retention Practices on Firm Performance in the Retailing Sector: \\ A comparison between a foreign and home grown retailer in Malaysia
}

\author{
Dr. Gengeswari, K. and Padmashantini, P. \\ University Tunku Abdul Rahman, Department of Marketing, Faculty of Business and Finance, Perak Campus, \\ Jalan Universiti, Bandar Barat, 31900 Kampar, Perak, Malaysia. \\ gengeswarik@utar.edu.my \\ padmasp@utar.edu.my
}

\begin{abstract}
As customers are the backbone of any business, firms without customers would not be able to sustain their performance. This is because such firms are believed to have no revenues, no profits and therefore no market value. Accordingly, managing customers is deemed to be very crucial business agenda in which the key focus has been switched in recent years from attracting new customers to preserving existing ones. Both practitioners and scholars have discovered that it is much easier and cheaper to retain the exiting customers than investing on the potential customers. A decent customer retention level is believed to be a significant contributor towards improvement in the overall firm performance. A glimpse on the existing researches on customer retention highlights that financial sector has been thoroughly investigated which leave a room for a detailed investigation on customer retention within retailing sector. Accordingly, this study intends to explore the customer retention practices adopted by service-oriented firms in general and retailers in particular. As a comparison study on a foreign and home grown retailer, this study examines factors that retain customers and the subsequent impact of retention practices on firm's performance. This study had carried out mall-intercept surveys among 400 shoppers at two major retailers within Klang Valley, Malaysia.Findings show that influencing factors of retention practices and type of retailer (namely foreign and home grown) significantly influencesthe retailer's customer retention practices. It was also discovered that the inclusion of retailer's type had enhanced the relationship between influencing factors and retailer's retention practices. In addition, it was also found that customer retention practices significantly affect retailer's performance at a moderate level. This study has uncovered that customers are in deed price sensitive despite being loyal and retained by firms. Hence, it is advisable for retailers to pursue a genuine pricing strategy to appeal to price conscious customers. The pricing strategy ideally should be transparent (i.e. no-bogus sales), clarity (i.e. provide accurate details of merchandises), simplicity (i.e. avoid psychological pricing) and trustable (i.e. provide accurate balances).
\end{abstract}

\section{Indexing terms/Keywords}

Customer retention, non-financial performance measures, measures of customer retention, influencing factors of customer retention, customer satisfaction, retailing and service sector.

\section{Academic Discipline And Sub-Disciplines}

Marketing; Customer Retention; Consumer Behaviour; Retailing

\section{SUBJECT CLASSIFICATION}

Consumer Behaviour and Practices

TYPE (METHOD/APPROACH)

Quantitative approach with mall-intercept survey

\section{Council for Innovative Research}

Peer Review Research Publishing System

Journal: International Journal of Management \& Information Technology

\author{
Vol. 6, No. 1 \\ editor@cirworld.com \\ www.cirworld.com, member.cirworld.com
}




\section{INTRODUCTION}

The agriculture sector has been appreciated for its noteworthy contribution towards the development of the global economy in 1900s; nevertheless, the economy was swiftly overhauled by the prominence of the manufacturing sector since 1960s (Memodovic \& Lelio, 2010). Despite its preeminence, the sector gave way to the eminent economic contribution of the service sector from late 1990s (Lee \& Lee, 2002; Karmarkar, 2004; Memodovic \& Lelio, 2010).

Such transformation of economic structure had also ensued in the Malaysian economy (Public Bank Economic Review, 2008) wherein Malaysia is currently at the third stage of the economic development with great emphasis on serviceoriented business activities (Economy Watch Content, 2010). Industrial Master Plan (IMP3) was then created to transform Malaysia into a major trading nation by concentrating on services and human capital (Economy Watch Content, 2010). Today, the service sector is undeniably the top contributor of Gross Domestic Product (GDP) for the Malaysian economy followed by the once dominated economic sector i.e. manufacturing and agriculture (Lindsay, 2012; MITI Weekly Bulletin, 2013). It is also worth mentioning that contribution from the service sector has been growing from $54.2 \%$ in 2011 to $54.6 \%$ in 2012; on the contrary, the contribution of other key economic sectors i.e. manufacturing and agriculture has been declining from $25.1 \%$ to $24.9 \%$ and from $7.7 \%$ to $7.3 \%$, respectively (MITI Weekly Bulletin, 2013).

Furthermore, Malaysia was also recognized for its ranking in the list of world's 30 largest exporters of services in 2010 comprising both developed and developing nations (Trade Chakra, 2012). As such, it could be wisely ascertained that the said ranking and GDP contribution undeniably emphasizes on the importance of the service sector towards the growth of the Malaysian economy.

The Malaysian services sector can be further categorized into 12 sub-sectors in line with the classification of the Trade Organization as the following: business, communication, construction, distribution, education, environment, financial, healthcare, tourism, transportation, recreational \& cultural and others (http://myservices.miti.gov.my). In line with the growing importance of the services sector, investment in these sub-service sectors has been also rising from 3301 projects (RM36742.5 million) in 2010 to 3957 projects (RM64352.8 million) in 2011 ("MIDA Malaysia Investment Performance", 2011).

Of these sub-sectors, the distribution trade sector is leading the others in terms of number of projects invested where majority of these projects were funded by local investors (http://www.mida.gov.my/). Concentration of by local investors could be justified due to the nature of this sub-sector, which comprises of more small and medium sized enterprises (SMEs) and hence, this sector is also recognized as one of the potential growth areas for the development of SMEs in Malaysia (http://myservices.miti.gov.my). Besides, this sector is also the second biggest contributor to the Malaysian Gross National Income (GNI) among the 12 Key Economic Areas (NKEAs) which were introduced under the 10th Malaysian Plan (Mustaza, 2012). This sector essentially consists of wholesalers and retailers who channel their goods to end users (http://myservices.miti.gov.my). Nevertheless, it has been reported that the major player in the overall distribution sector within Asian nations is retailing (Matsuura, 2004; Wrigley and Lowe, 2010).

Malaysian retailing sector has experienced remarkable changes where the expansion of retail premises' size from 1.2 million square metres in the early 1990 s to over 8 million square metres in 2010 s and shift in consumers' preference to shop at bigger retailers instead of smaller sundry shops are to name few ("Malaysian Retail Business", 2011; Inside Malaysia, 2012). Accordingly, this sector had recorded higher sales growth of $7.5 \%$ in the first quarter of 2013 compared to its initial prediction of $5.9 \%$ (Star Online, 2013). Such growth has been the common phenomenon in this sector over the past years (Matsuura, 2009; Star Online, 2013). This implies that retailing the sector is indeed one of the key contributors for the growth of the nation's economy.

This sector is greatly led by large chains of hypermarkets and supermarkets, such as Giant, Tesco, AEON, Mydin and Econsave with total contribution of $15 \%$ towards the overall retail earnings in Malaysia (Inside Malaysia, 2012). To date, the Malaysian retailing sector comprises of 121 hypermarkets, 113 superstores and 113 departmental stores owned by foreign and local companies. In addition, Malaysia is also known for seizing the largest share of foreign grocery operators in the Asia Pacific Region. It has clearly signalled an intense competition among the players in this sector.

Competition within an industry is predicted to be greater during the individual firm's maturity period where retaining an existing customer is greatly considered as a strategic weapon instead of acquiring new ones during such critical period (Dawkins \& Reichheld, 1990; Kotler, Philip, Armstrong, Gary, Saunders, John, Wong \& Veronica, 1999; Addai-Minkah, 2011; Kwon and Kim, 2012). This is due to the steady increases in customer turnover which results into approximately $15 \%$ to $30 \%$ customer defection rate annually across all economic sectors (Baxter Strategies Incorporated, 2004). This had forcibly made the firms to swap the majority of their customer base every few years (Baxter Strategies Incorporated, 2004; Kwon and Kim, 2012; "Customer Retention Statistics", 2013). Subsequently, firms which are not dominating their respective market need to focus on keeping their customers for an extended period (Page, Pitt and Berthon, 1996; Kotler et al. 1999). In order to seize the promising benefits resulted from retention strategies, retailers worldwide were found to greatly rely on the innovative customer retention strategies (Fiorletta, 2012). According to Fiorletta (2012), survey conducted among 129 marketing executive of major retailers showed that customer retention practices are already in place at the majority $(84.5 \%)$ of retailers; nevertheless, only $44 \%$ of these retailers believe that their retention practices are effective.

Recent statistics had discovered that a firm's profit could be augmented by 25 to $95 \%$ with a mere $5 \%$ improvement in customer retention rate by while $80 \%$ of the firm's future sales normally originate from $20 \%$ of the firm's existing customers (“Customer Retention Statistics", 2013). This has demonstrated the importance of customer retention practice to improve 
firm's profit in particular and firm's performance, in general. Review on past literatures indicates that firm performance is normally associated and computed using either accounting or financial state such as profit, operational costs, market share and others (Gupta \& Zeithaml, 2006; Avci et al. 2010). Nevertheless, both practitioners and academics in the service sectors claimed that firm performance should not be assessed solely based on the financial dimensions (Kaplan and Norton, 2001; Reichel and Haber, 2005). Hence, consideration on the non-financial performance (NFP) metrics is also equally important in measuring the performance of firms particularly within service sector (Kaplan and Norton, 2001; Ryals and Knox, 2005; Avci et al. 2010).

In view of the importance of the retailing sector towards the nation's development and its players' apprehension to retain the existing customers from switching to competitors, this study attempts to explore factors utilized by two major retailers in retaining their customers. The chosen retailers are essentially the top local and foreign retailer operating in Malaysia. This study also intends to examine the impact of the resultant customer retention practice towards these retailers' nonfinancial performance as perceived by their customers.

\section{LITERATURE REVIEW}

\section{Introduction to Customer Retention}

Customer retention is seen as an obligation by a customer to carry out business transactions with a particular firm on a regular basis (Hansemark \& Albinsson, 2004). In addition, Molapo and Mukwada (2011) have ascertained that firms are all out to foil attempts by customers to switch retailers and indirectly retain them. In addition, Erdis (2009) has established that firms direct their marketing efforts to please their current customers in order to retain them and foster long-term relationships with them. Customers will frequently patronise firms which meets their needs and hence, an enduring relationship will be fostered (Fill, 2005).

Farquhar (2004) claimed that retained customers increase firms' profits because acquiring new customers are a costly affair. This is in line with the findings of Reichheld and Schefter (2000) which ascertained that firms that are able to raise customer retention by five per cent would be able to boost profits by 25 - 95 per cent. In addition, the costs of acquiring new customers are five times more than retaining an existing customer for a firm (Tu, Lin, \& Chang, 2011). Thus, boosting customer retention will increase firm's profits and performance by leaps and bounds (Sim, Mak \& Jones, 2008).

\section{Non-Financial Performance Measures}

Financial performance (FP) measures namely profit, return on investment (ROI), market share and stakeholder value has been the preferred measure of firm performance among researchers (Avci, Madanoglu \& Okumus, 2011). However, academics and practitioners have agreed that in measuring the performance of service firms, non-financial performance (NFP) measures should be given importance (Gupta \& Zeithaml, 2006). Furthermore, the NFP measures would be most suitable due to the characteristics of services such as intangibility, heterogeneity and participation of customers with varied requirements in the service process (Reichel \& Haber, 2005). Hence, the most widely used NFP measures are innovation, internal business process efficiency as well as customer and employee satisfaction (Avci et al. 2011). The main objective of service firms is to satisfy customers and build win-win relationship with them (Kotler, 2005). Hence, customer satisfaction has been identified as the essential component for measuring the non-financial performance of service firms (Anderson, Fornell \& Mazvancheryl, 2004).

According to Caruana (2002), customer satisfaction is derived by comparing the difference between customer's prior anticipation and the actual accomplishment of the product or service. Furthermore, Singh (2006) has ascertained that customer satisfaction is normally related to emotions such as excitement, relief, happiness, acceptance and delight. Satisfied customers could be easily retained where they will continue shopping at a firm for a prolonged period of time despite there is no contractual agreement between the customer and the firm (Gan, Cohen, Clemes \& Chong, 2006). Thus, customers are at ease when they purchase and this increases firm's sales volume and indirectly firms' performance (Anderson et al. 2004).

\section{Measures of Customer Retention}

Kotler (2005) had ascertained that the main goal of a firm is to satisfy the customer and at the same time to foster lasting and equally lucrative relationships with customers. Hence, it is perceived that retained customers tend to be committed and loyal to a firm by engaging in repeat purchases (Oyeniyi \& Joachim, 2008). Repeat purchase is expressed as an intense obligation to continuously purchase and repurchase a service in the future (Haghighi, Dorosti, Rahnama \& Hoseinpour, 2012). Repeat purchases also indicate that customers are satisfied with the firms' offerings (Hueng \& Ngai, 2008). Repeat customers will essentially buy the same or other services during their consequent visits without considering other retailers (Wilkins, Merrilees \& Herington, 2010). This customer in turn will suggest to their social circles to purchase and continue purchasing in the future from a particular firm and increase firm's performance levels (Ang \& Buttle, 2006). It is widely known that customers who hold a favourable attitude towards a firm would put in a good word regarding the firm to their social contacts (Bowen \& Chen, 2001). Word-of-mouth is viewed as the customers' enthusiasm in recommending a particular firm to their social circles (Mazzarol, Sweeney \& Soutar, 2007; Kumar, Andrew \& Robert, 2007). Customers usually spread positive word-of-mouth regarding a particular firm especially when they are delighted with the services received (Rasha, 2006). Customer's attitudes and behaviours are easily affected by positive word-of-mouth which would eventually enhance their withholding towards the firm and hence, customer satisfaction (Mazzarol et al. 2007).

Besides, price insensitivity is another measure that can be used in measuring customer retention rates (Dawes, 2009). A retained customer will be more than willing to pay higher prices for services offered by a firm (Farquhar, 2004). On the 
other hand, a retained customer who has high price tolerance levels would most likely shop during off-sales and during non-festive seasons (Ang \& Buttle, 2006). According to Hennig-Thurau (2004), a retained customer is ever willing to pay any prices set by a firm mainly because they are satisfied with the services offered by the firm. In addition, Hueng and Ngai (2008) claimed that retained customers seek for value instead of low prices while purchasing and this boost customer retention rates consequently. Past findings ascertained that retained customers also rarely grumble or show their disappointment towards the services offered by firms (Woo \& Fock, 2004). According to Kumar et al. (2007), customer who never complain and spread negative comments regarding a firm's services are known to exhibit non-complaining behaviour. These customers are normally satisfied with the firm's offerings.

To sum, customers' non-complaining behaviour, price insensitivity, tendency to spread positive word-of-mouth and engagement in repeat purchases are inherently evidenced to augment the firm's customer retention practice (HennigThurau, 2004; Fill, 2005; Kotler, 2005; Rasha, 2006; Mazzarol et al. 2007; Kumar et al. 2007; Hueng \& Ngai, 2008; Erdis, 2009). It has been also discovered that these retained customers tend to be easily pleased and hence satisfied (Rasha, 2006; Mazzarol et al. 2007; Erdis, 2009).

\section{Influencing Factors of Customer Retention}

Support from top management plays an important role in retaining customers (Farquhar, 2004). Top management support can be viewed as the structured guidance from the top guns of a firm which in turn facilitates customer retention rates (Wadongo, Odhuno, Kambona \& Othuon, 2010). Firms generally need commitment from the top management team to retain and satisfy their customers (Villanueva \& Hanssens, 2007). Yee, Yeung and Edwin (2010) emphasized on the importance of providing service assurance to customers such as money back guarantee or refunding if the service fails. It is perceived that such assurance is vital to retain a customer. Managements' support is a must to provide the said service assurance by enforcing policies on refunds to be highly competitive in the marketplace (Venetis \& Ghauri, 2004). Hence, retaining customers is highly possible only with the constant support from the top management of the firm (Farquhar, 2004; Villanueva \& Hanssens, 2007; Wadongo et al. 2010; Yee at al. 2010).

Price is an important tool in retaining customer (Dawes, 2009). Customers are seen as value maximisers (Kotler \& Keller, 2006) who normally perceive that the price of a service signifies value for money and believe in trade off between price and quality (Yuksel \& Yuksel, 2003; Wang, 2010). Similarly, Polo, Sese and Verhoef (2011) emphasized on the importance of setting reasonable prices for services offered by firms in order to attract and retain customers in the long run. Satisfaction of retained customers is conditional on the distinguishable value for money (Voon, 2011) as attractive prices mirror the perceived quality of the service by the consumers (Jin, Lee \& Huffman, 2011). Therefore, the competitive price of services set by a firm facilitates the practice of customer retention (Dawes, 2009; Polo et al., 2011).

Behaviour of responsive and dependable employees in serving and assisting customers plays a vital role in accelerating firm's retention rate and subsequently the intensity of customer satisfaction (Liao \& Chuang, 2004; Ryu, Lee \& Kim, 2011). Responsiveness is the enthusiasm to assist consumers and deliver services on time whereas dependability is the ability to deliver services precisely, reliably and consistently to consumers (Sayuti, 2011). Helpful, knowledgeable and wellmannered employees are also key contributors towards the customer retention rates (Liao \& Chuang, 2004; Sayuti, 2011).

Relationship marketing is an important tool that fosters interactive interaction or better known as two way communication with customers (Roberts, Varki \& Brodie, 2003). Customer retention is known for its reliance on the extent of firm's twoways communication in maintaining relationship with its customers (Reinartz \& Kumar, 2003). Firms' frequent interaction and inclination to obtain feedback from customers besides maintaining continuous contact with customers are the key instruments to foster retention rates (Gupta, Hanssens, Hardie, Kahn, Kumar, Lin, Ravishankar \& Sriram, 2006; Bassey, Okon \& Umorok, 2011). For this reason, it has been identified that interactive interaction with customers of a firm enables customer retention (Reinartz \& Kumar, 2003; Gupta et al. 2006; Bassey et al. 2011).

Membership programs influence customer retention rates as it provides opportunities for firms to interact with their customers on a regular basis besides learning about them (Stengel, 2003). The membership card provides vital information regarding the customer namely income, spending patterns, likes, dislikes, and preferred mode of payment (Arnold, Fang \& Palamtier, 2011). In addition, Currah and Wrigley (2004) ascertained that customers' personal information obtained from the membership program's database would facilitate firm's marketing communication efforts and retention practice in the long run. Card members usually feel a sense of attachment with firms when they are awarded vouchers and this satisfies them (Bolton, Kannan, \& Bramlett, 2000). To sum, membership programs indeed facilitates customer retention by firm (Bolton et al., 2000; Stengel, 2003; Currah \& Wrigley, 2004).

It is perceived that retaining customers is feasible due to the reluctance of customers to bear the total switching cost (Ranaweera \& Prabhu, 2003; Steven et al., 2012). Switching cost can be described as the total cost incurred by consumers when they switch to other firms (Gustafsson, Johnson \& Roos, 2005). Moreover, Seo, Ranganathan and Babad (2008) perceived switching cost could be incurred in terms of time loss to source for a new retailer, monetary loss in the searching process and other hidden cost. Customers are also normally reluctant to change service providers due to their concerns over the loss of the membership points (Steven, Dong \& Dresner, 2012). It is wise to conclude that customer retention depends on switching cost to a great extent (Ranaweera \& Prabhu, 2003).

Firms are stressing on service quality to the extend that it has been made an integral component of a firms' business plan (Samat, Ramayah \& Norizan, 2006). Similarly, it has been acknowledged as one of the important factors in retaining customers (Sayuti, 2011). According to Tu et al. (2011), perceived service quality is the gap between the expected customer service and the actual customer service from firm. Venetis and Ghauri (2004) have emphasized that quality of services rendered affects the future repurchase intention and firms that have demonstrated excellent pre and post 
customer assistance is able to preserve their customers. Therefore, it is highly plausible to retain customers when they perceive firms to offer good quality of services (Venetis\& Ghauri, 2004; Sayuti, 2011).

Customer retention is highly dependent on customer relationship management (CRM) (Omar, Musa \& Nazri, 2007). Customer relationship management essentially encompasses any efforts by firms to carry out activities focused on relationship building where these activities can be carried out traditionally or by electronic means (Feinberg \& Kadam, 2002). CRM and electronic CRM are widely associated with effective service recovery processes particularly targeted at dissatisfied customers (Ndubisi, 2007). Moreover, Yunus (2009) has pointed out that (E) CRM activities include fostering pleasant and enjoyable rapport with customers by communicating the latest promotions and updates to them which will in turn satisfy them. Consequently, such impressive CRM activities would lead to firm's customer retention practice (Omar et al. 2007; Yunus, 2009).

Customer service is viewed as the customers' opinion of a firm based on certain visible features namely the surroundings, location and the mood inflicted on the customer in comparison with other firms (Razak, Chong \& Lin, 2007). Customer service is considered an important weapon to retain firm's customers (Al-Eisa \& Alhemoud, 2009; Voon, 2011). Voon (2011) has ascertained that customers' decision to stay with a firm is greatly influenced by the physical amenities and surroundings of a firm such as noise, music, lighting, temperature, store layout, arrangement of furniture and equipment, decor and signage. Furthermore, customers' decision to stay retained with a firm is also based on the store appearance as firm's unique ambience would be difficult to emulate (Eliwa, 2006). On the other hand, Vesel and Zabkar (2010) have ascertained that customers judge the quality of customer service based on a few encounters. Delighted customers are normally able to tolerate unpleasant customer service encounters if they happen once in a blue moon (Bolton et al. 2000). Thus, it could be concluded that retaining customers is achievable with the above average customer service offered by firms (Eliwa, 2006; Al-Eisa \& Alhemoud, 2009; Voon, 2011).

\section{Proposed Research Framework}

Figure 1 depicts the research framework developed for this study. This framework was developed based on an extensive review on the past literatures as discussed above. As shown in Figure 1, influencing factors namely top management, price, employees, interaction, switching cost, perceived service quality, membership, customer service and CRM are claimed to influence the firm's customer retention practices. The customer retention practices are essentially measured via the customers' repeat purchases, tendency to spread word-of-mouth, price insensitivity and non-complaining behaviour. These practices are subsequently perceived to affect the firm's non-financial performance particularly customer satisfaction.

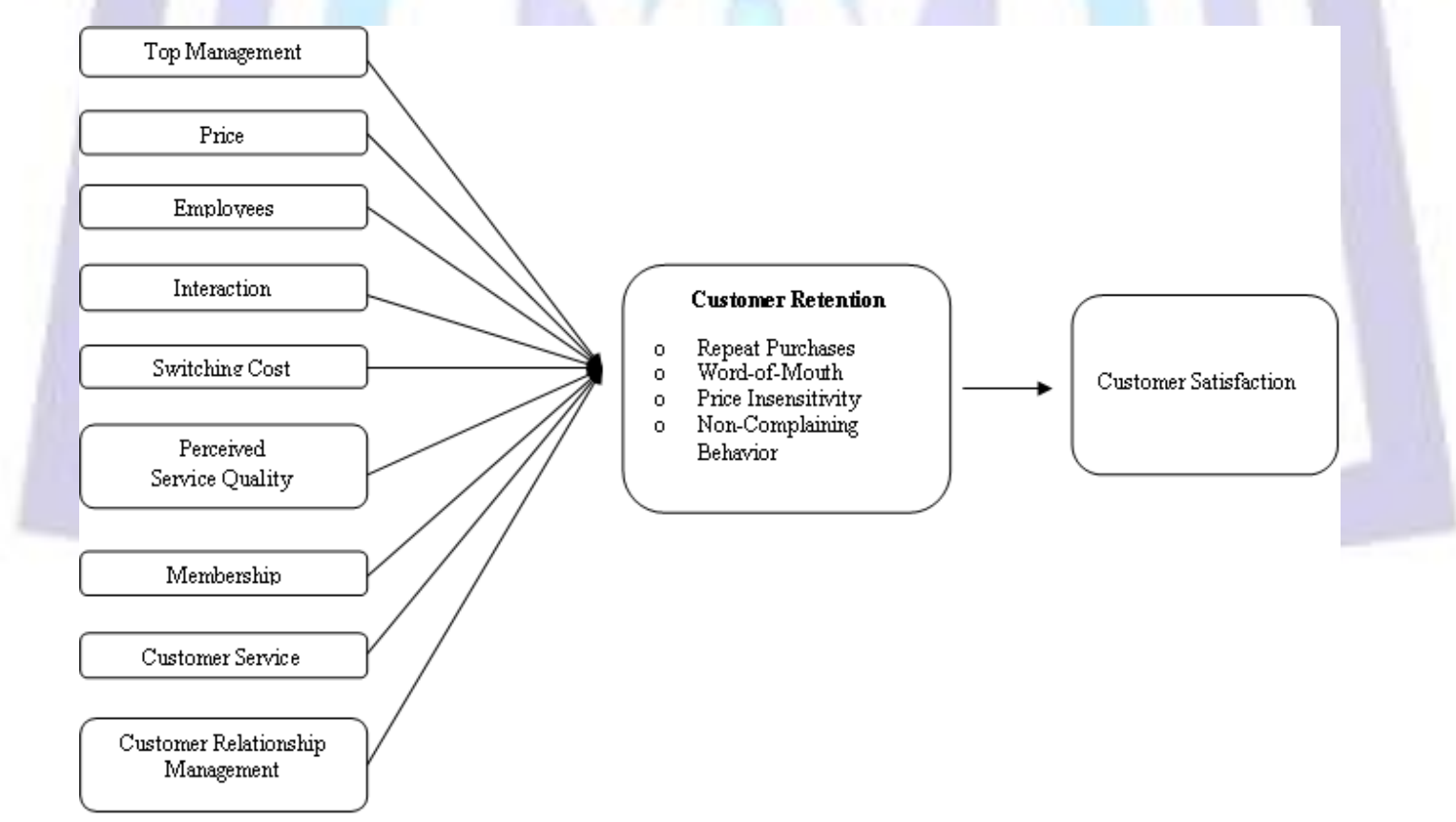

Figure 1: Proposed Research Framework

\section{RESEARCH METHODOLOGY}

In this study a quantitative descriptive design with cross-sectional approach was employed. The descriptive design was chosen to further describe the variables measured. Self administered questionnaire was distributed via mall intercept approach. Mall-intercept survey was executed at the selected retailers in Klang Valley due to the suitability of this approach in line with the nature of study's focal point namely retailers.

Respondents were approached as they were leaving the cash counters in order to minimize interferences during their shopping. It is believed that such approach provided respondents ample time to complete the survey form. The target population of this study consists of customers who hold membership cards of chosen retailers in Malaysia, in general and 
Klang Valley, in particular. The said retailers are one home-grown and one foreign, respectively in order to highlight the varying practices of customer retention between the local and foreign operator. On the other hand, membership card holders were chosen due to their good relationship resultant of their frequent purchases and loyalty (Farquhar, 2004).

Judgmental sampling technique was employed where the target respondents were at least 18 years old and above membership card holders of the respective retailers. It should be noted that there was a glitch in obtaining the details of the target population due to the inaccessibility of appropriate sampling frame. According to Voorhis and Morgan (2007), a minimum of 50 elements are required to investigate relationships. Hence, it was decided to investigate 200 elements from each of the chosen retailers. This is because the larger a sample size, the more reliable the results of the study (Malhotra, 2010). The final sample size of this study was then 400 elements.

A questionnaire was formulated based on the reviews of past researches. The questionnaire was divided into two components (i.e. Section A and Section B) which centers on the respondent's demographic profile and research variables, respectively. The differences in respondent's responses were measured using five-point likert scale (i.e. $1=$ strongly disagree and $5=$ strongly agree). Pilot test was then carried out among 30 shoppers at the chosen retailers. Feedbacks of the respondents from the pilot test were taken into consideration in order to enhance the quality of the research instrument.

The data analysis was conducted to explore customer retention practices among major retailers and to analyse the resulting impact on the firm's non-financial performance. Initially, 400 completed questionnaires were tested for content and construct validity. Besides obtaining preliminary feedbacks on the overall quality of the questionnaire, pilot study was also intended to ascertain its content validity. It was tested by the respondents who assessed the suitability of the questions asked.

On the other hand, construct validity was examined using factor analysis. The factor analysis is essentially used to reduce and summarize large volume of data. Factor loading value was referred to retain the attributes of the variables measured The higher the said value, the greater is the representation of the attributes towards the factor or construct generated. In this study, attributes with 0.5 value and above only were considered for further analysis (Malhotra, 2012). Reliability test is used to measure the consistency of variables. Cronbach's Alpha value is used to assess the internal consistency of data collected. The Cronbach's alpha value should be more than 0.6 and preferably closer to 0.9 (Malhotra, 2010).

Independent sample t-test was used to measure the variation in customer retention practices between two chosen retailers (Malhotra, 2010). Descriptive mean, Levene's test and t-test were referred to assess the overall variation in practices by individual retailers.

Multiple-regression was also used to examine the relationship between influencing factors and customer retention which were measured using interval scale. The relationship is considered as significant with the $p$-value of less than 0.05 (Malhotra, 2010). Besides, Beta coefficient value was also referred to identify the contribution of individual influencing factors towards the retention practice. Meanwhile, the adjusted $R^{2}$ was utilized to explain the variance in retention practices resultant of influencing factors. Further, simple linear regression analysis was used to examine the impact of customer retention practice towards firm's non-financial performance.

Furthering the analysis, hierarchical regression was employed to determine the impact of retailers' country of origin (homegrown and foreign) towards the customer retention practice and its influencing factors. The change in F-value provides a distinct perception whether the inclusion of country of origin is a significant factor while holding the other variables constant.

\section{ANALYSIS AND DISCUSSION}

\section{Measurement of Accuracy}

It is vital to assess validity of the data collected in order to understand what is actually intended to be measured (Malhotra, 2010). Two approaches were used in this study to measure validity. Content validity was tested during the pilot study where respondents were asked to check on the suitability of the attributes measured via questionnaires. In addition, construct validity was tested via factor analysis. This approach was employed to assess the extent to which the attributes joined onto factors generated from factor analysis could allow an insightful judgment in accordance with existing theories (George \& Mallery, 2001; Burton \& Mazerolle, 2011). In this study, factor analysis was conducted on the influencing factors and measures of customer retention. Attributes with factor loading value of 0.5 and below were deserted from further analysis in ensuring the construct validity of measurement used (George \& Mallery, 2001).

Table 1 illustrates the output of factor analysis conducted on the influencing factors of customer retention. Of 45 attributes, 6 were withdrawn due to their lower factor loading value. The remaining attributes were grouped into 6 factors and renamed as (i) Policy \& Price, (ii) Customer Service, (iii) Employees, (iv) Switching Cost, (v) Added Value and (vi) Interaction. All these factors explain $67.10 \%$ of overall variance where factor of Policy \& Price accounts $39.86 \%$ of variance followed by factor of Customer Service (11.16\%), Employees (5.16\%), Switching Cost (4.91\%), Added Value $(3.16 \%)$ and Interaction (2.85\%). The result is in line with several past studies which claimed that dimensions related to firm's corporate policy and pricing strategy, provision of good customer service, an excellent pool of employees, customers' avoidance towards switching cost, perceived added value by the firm and two-way communication are the key elements which facilitate firm's customer retention practice (Seo et al. 2008; Wadongo et al. 2010; Polo et al. 2011; Sayuti, 2011; Bassey et al. 2011; Arnold et al. 2011; Voon, 2011). 
On the other hand, Table 2 illustrates the output of factor analysis conducted on the measures of customer retention. In contrast to the influencing factors of customer retention, all the attributes of customer retention's measures were retained due to their higher loading value besides grouped in a meaningful manner without much change to their original structure. The grouped factors are (i) Customer's Bonding, (ii) Price Insensitivity and (iii) Non-complaining behavior with 54.37\%, $9.61 \%$ and $5.60 \%$ of variance, respectively. It is worth to mention that a good relationship between a firm and customers can be established via customers' repeat purchases and tendency to spread remarks about the firm; such bond is claimed to be an effective measurement of firm's retention practice (Rasha, 2006; Haghighi et al. 2012). It should be noted that there is a slight change in the original structures of variables measured via factor analysis (refer to Table 3). Nevertheless, the grouping of these variables is in deed done in a meaningful manner and is in line with the notion of the study's research framework. It can be then wisely asserted that the variables measured in this study have adequate criterion validity.

Table 1: Factor Analysis - Influencing Factors

\begin{tabular}{|c|c|c|c|c|c|c|}
\hline Details & $\begin{array}{l}\text { Policy \& } \\
\text { Price }\end{array}$ & $\begin{array}{l}\text { Customer } \\
\text { service }\end{array}$ & Employees & $\begin{array}{l}\text { Switching } \\
\text { cost }\end{array}$ & $\begin{array}{l}\text { Added } \\
\text { value }\end{array}$ & Interaction \\
\hline Firm's vision to satisfy customers & 0.7392 & & & & & \\
\hline Firm often updates their offerings & 0.7798 & & & & & \\
\hline Simple refund/replacement process & 0.7346 & & & & & \\
\hline $\begin{array}{l}\text { Firm is committed to satisfy } \\
\text { customers }\end{array}$ & 0.7894 & & & & & \\
\hline $\begin{array}{l}\text { Comfortable and conducive } \\
\text { shopping environment }\end{array}$ & 0.7694 & & & & & \\
\hline Competitive pricing & 0.7729 & & & & & \\
\hline Worthwhile to spent & 0.7811 & & & & & \\
\hline Happy with pricing of products & 0.7899 & & & & & \\
\hline $\begin{array}{l}\text { Often shop due to competitive } \\
\text { pricing }\end{array}$ & 0.7540 & & & & & \\
\hline Attractive pricing & 0.7040 & & & & & \\
\hline Pleasant ambience & & 0.6580 & & & & \\
\hline Satisfied with customer service & & 0.7505 & & & & \\
\hline $\begin{array}{l}\text { Good relationship between } \\
\text { customers and employees }\end{array}$ & & 0.7827 & & & & \\
\hline $\begin{array}{l}\text { Tolerable with rare poor customer } \\
\text { service }\end{array}$ & & 0.7370 & & & & \\
\hline Ample parking space & & 0.6195 & & & & \\
\hline $\begin{array}{l}\text { Attempt to solve customers' } \\
\text { problem }\end{array}$ & & 0.6739 & & & & \\
\hline Effort by employees & & 0.6896 & & & & \\
\hline $\begin{array}{l}\text { Prioritize relationship with } \\
\text { customers }\end{array}$ & & 0.6954 & & & & \\
\hline Exceptional remedial actions taken & & 0.7460 & & & & \\
\hline Good communication & & 0.7007 & & & & \\
\hline Knowledgeable employees & & & 0.6976 & & & \\
\hline Well trained employees & & & 0.7234 & & & \\
\hline Helpful employees & & & 0.7744 & & & \\
\hline Informative employees & & & 0.7832 & & & \\
\hline
\end{tabular}




\begin{tabular}{|c|c|c|c|c|c|c|}
\hline $\begin{array}{l}\text { Employees put effort to solve } \\
\text { customers' problems }\end{array}$ & & & 0.6736 & & & \\
\hline $\begin{array}{l}\text { Two way communication with } \\
\text { employees }\end{array}$ & & & 0.5297 & & & \\
\hline $\begin{array}{l}\text { I will not shop at other retailers due } \\
\text { to convenient location }\end{array}$ & & & & 0.7373 & & \\
\hline $\begin{array}{l}\text { I'm concerned of my } \\
\text { points/rewards. }\end{array}$ & & & & 0.7946 & & \\
\hline $\begin{array}{l}\text { Time consuming to familiarize with } \\
\text { a new retailer. }\end{array}$ & & & & 0.7826 & & \\
\hline $\begin{array}{l}\text { I will not waste my resources by } \\
\text { shifting to others }\end{array}$ & & & & 0.7659 & & \\
\hline $\begin{array}{l}\text { Continue shopping at Giant to } \\
\text { avoid additional cost }\end{array}$ & & & & 0.6432 & & \\
\hline $\begin{array}{l}\text { Products can be tested before it is } \\
\text { purchased. }\end{array}$ & & & & & 0.6095 & \\
\hline Convenient shopping & & & & & 0.6033 & \\
\hline Excellent customer support & & & & & 0.4594 & \\
\hline Cash vouchers to customers. & & & & & 0.7630 & \\
\hline Offer weekly specials & & & & & & 0.6163 \\
\hline Value customer feedbacks & & & & & & 0.5366 \\
\hline Interactive communication & & & & & & 0.5993 \\
\hline Eigen values & 15.943 & 4.465 & 2.064 & 1.963 & 1.266 & 1.140 \\
\hline$\%$ of variance & 39.856 & 11.163 & 5.161 & 4.907 & 3.164 & 2.85 \\
\hline
\end{tabular}

Table 2: Factor Analysis - Measures of Customer Retention

\begin{tabular}{|c|c|c|c|}
\hline Details & Bonding & PI & NCB \\
\hline Frequently shop & .765 & & \\
\hline Shopping for sometime & .839 & & \\
\hline Do not prefer to shop at other stores & .722 & & \\
\hline Delighted to shop & .762 & & \\
\hline Prefer to purchase here & .731 & & \\
\hline Spending increases over time & .643 & & \\
\hline Always recommend to others & .725 & & \\
\hline Frequently share information & .730 & & \\
\hline Suggest the retailer & .718 & & \\
\hline Volunteer to be the spokesperson & .552 & & \\
\hline Willing to spend more & & .668 & \\
\hline Continue shopping without discount & & .839 & \\
\hline $\begin{array}{l}\text { Shopping decision is due to non-pricing } \\
\text { factors }\end{array}$ & & .840 & \\
\hline
\end{tabular}




\begin{tabular}{|c|c|c|c|}
\hline Shopping after sales & & .765 & \\
\hline Worthwhile to shop & & .530 & \\
\hline Never complain to queue up & & & .655 \\
\hline Never spread negative remarks & & & .721 \\
\hline Acknowledge good customer service & & & .776 \\
\hline Happy with assistances provided & & & 739 \\
\hline Rarely dissatisfied & & & .707 \\
\hline Eigen values & 10.874 & 1.922 & 1.119 \\
\hline$\%$ of variance & 54.372 & 9.61 & 5.596 \\
\hline
\end{tabular}

Table 3: Comparison between Variables of Research Framework and Factor Analysis

\begin{tabular}{|c|c|}
\hline Research Framework & Factor Analysis \\
\hline \multicolumn{2}{|c|}{ Influencing factors of customer retention } \\
\hline Top management & \multirow{2}{*}{ Price \& policy } \\
\hline Pricing & \\
\hline Customer service & \multirow{2}{*}{ Customer service } \\
\hline CRM & \\
\hline Employees & Employees \\
\hline Switching cost & Switching cost \\
\hline Perceived service quality & \\
\hline Membership & 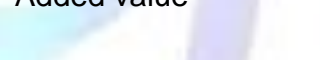 \\
\hline Interaction & Interaction \\
\hline \multicolumn{2}{|c|}{ Measures of customer retention } \\
\hline \multicolumn{2}{|l|}{ Repeat purchase } \\
\hline \multicolumn{2}{|l|}{ Word-of-mouth } \\
\hline Price insensitivity & Price insensitivity \\
\hline Non-complaining behavior & Non-complaining beha \\
\hline
\end{tabular}

Besides measuring the validity of data collected, reliability analysis should be also done to assess the consistency of results generated from data collected over time (Malhotra, 2010). This study had tested the reliability by measuring the instrument's internal consistency. As shown in Table 4, all the variables investigated were found to have more than 0.6 Cronbach's alpha value. Such fair alpha value implies that the instrument used in this study has an adequate level of reliability.

Table 4: Internal Consistency Reliability

\begin{tabular}{|c|c|c|}
\hline Variable & Cronbach's alpha & No.of items \\
\hline Policy \& price & 0.949 & 10 \\
\hline Customer service & 0.925 & 6 \\
\hline Employees & 0.907 & 5 \\
\hline Switching cost & 0.682 & \multicolumn{2}{|c|}{} \\
\hline
\end{tabular}




\begin{tabular}{|c|c|c|}
\hline Added value & 0.828 & 4 \\
\hline Interaction & 0.871 & 10 \\
\hline Bonding & 0.941 & 5 \\
\hline Price insensitivity & 0.886 & 5 \\
\hline Non complaining behavior (NCB) & 0.891 & 5 \\
\hline Customer satisfaction & 0.906 & 63 \\
\hline Overall & 0.911 & \multicolumn{2}{|c|}{} \\
\hline
\end{tabular}

\section{Analysis on Respondents' Profile}

The response rate of this study was $100 \%$ due to the nature of the data collection method employed (i.e. in-person administered questionnaire) which resulted into a comprehensive participation of all the target respondents. Majority of the respondents were female shoppers, aged 40 and below, married, with tertiary qualifications and with monthly income of RM 4500 and below. Independent sample t-test and one-way analysis of variance (ANOVA) were employed to examine the possible variation in retailer's customer retention practice due to varied demographic characteristics of respondents. Nevertheless, the findings indicate that the variation is insignificant.

Table 5: Profile of Respondents

\begin{tabular}{|c|c|c|}
\hline Details & No. & $\%$ \\
\hline \multicolumn{3}{|c|}{ Gender } \\
\hline Female & 203 & 50.8 \\
\hline Male & 197 & 49.3 \\
\hline \multicolumn{3}{|c|}{ Age } \\
\hline below 20 & 55 & 13.8 \\
\hline $21-30$ & 105 & 26.3 \\
\hline $31-40$ & 111 & 27.8 \\
\hline $41-50$ & 74 & 18.5 \\
\hline $51-60$ & 43 & 10.8 \\
\hline 60 above & 12 & 3.0 \\
\hline \multicolumn{3}{|c|}{ Marital status } \\
\hline Single & 176 & 44.0 \\
\hline Married & 224 & 56.0 \\
\hline \multicolumn{3}{|c|}{ Education } \\
\hline School leavers & 96 & 24.0 \\
\hline Certificate & 53 & 13.3 \\
\hline Diploma & 122 & 30.5 \\
\hline
\end{tabular}




\begin{tabular}{|l|c|c|} 
Undergraduate & 102 & 25.5 \\
\hline Postgraduate & 20 & 5.0 \\
\hline Professional qualifications & 7 & 1.8 \\
\hline \multicolumn{2}{|c|}{ Monthly income } \\
\hline Below 3000 & 193 & 48.3 \\
\hline $3001-4500$ & 142 & 35.5 \\
\hline $4501-6000$ & 57 & 14.3 \\
\hline 6000 above & 8 & 2.0 \\
\hline
\end{tabular}

\section{Factors and Measures of Customer Retention}

Table 6 summarizes the influencing factors and measures of customer retention practices by their respective mean and standard deviation value. Although customer service is considered as the key influencing factor due to its highest mean value, interaction and firm's policy \& pricing strategy factors are also considered equally important due to their comparable mean value. Meanwhile, switching cost factor is perceived as the least contributing factor due to its lowest mean value. This finding is contradicting to a notion which views customers are essentially reluctant to switch firms mainly due to their concern on tolerating switching cost such as loosing the privileges of membership (Ranaweera \& Prabhu, 2003; Steven et al. 2012).

On the other hand, customer's bond with firm is considered a vital element for retailers to retain their customers. This is similar to the output of factor analysis (Table 2) which highlighted the importance of the Bonding factor which has the highest percentage of variance. However, customer's price insensitivity is found to be unessential for retailers in preserving their customers. Conversely, past studies claimed that the retained customers would tolerable any prices set by firms as they are merely seeking for value instead of lower price (Hueng \&Ngai, 2008).

Table 6: Mean Computation

\begin{tabular}{|l|l|l|}
\hline Variables & Mean & Std. Deviation \\
\hline \multicolumn{2}{|c|}{ Influencing Factors } \\
\hline Policy and price & 3.4024 & .8780 \\
\hline Employees & 3.3071 & .7869 \\
\hline Switching cost & 3.0920 & 1.0350 \\
\hline Added value & 3.3460 & .8328 \\
\hline Customer service & 3.4289 & .7570 \\
\hline Interaction & 3.4201 & .7900 \\
\hline \multicolumn{3}{|c|}{ Measures of Customer Retention } \\
\hline Bonding & 3.2606 & .8717 \\
\hline Price insensitivity & 2.8615 & .8338 \\
\hline Non-complaining behavior & 3.1845 & .8297 \\
\hline
\end{tabular}

The overall mean value of customer retention practice is 3.102 (STD $=0.755$ ) where it indicates that generally respondents have moderate responses towards the measures of customer retention practices. Furthering the analysis, independent sample t-test was employed to assess the deviation in customer retention practices by the individual retailers. As shown in Table 7, the overall and all the measures of customer retention practices were found to vary significantly by 
the individual retailers. This had rejected an assumption on the equality of variances. In addition, t-test also indicates that, overall retention practices and its measures (except the factor of Price Insensitivity) significantly differ by the individual retailers. Briefly, the overall and measures of customer retention practices by Retailer 1 were considered greater compared to Retailer 2. This finding also reinforces the trivial role of customer's price insensitivity towards firm's efforts in retaining its customers.

Table 7: Independent Sample T-test Analysis

\begin{tabular}{|c|c|c|c|c|}
\hline Statistics & Bonding & PI & NCB & $\begin{array}{l}\text { Overall } \\
\text { CR }\end{array}$ \\
\hline Mean R1 & 3.413 & 2.931 & 3.299 & 3.214 \\
\hline STD R1 & .787 & .760 & .740 & .664 \\
\hline Mean R2 & 3.108 & 2.792 & 3.070 & 2.990 \\
\hline STD R2 & .926 & .898 & .898 & .816 \\
\hline \multicolumn{5}{|c|}{ Levene's Test for Equality of Variances } \\
\hline F-value & 17.445 & 4.302 & 11.571 & 16.792 \\
\hline Sign. value & .000 & 0.039 & .001 & .000 \\
\hline \multicolumn{5}{|c|}{ t-test for Equality of Means } \\
\hline t-value & 3.571 & 1.671 & 2.783 & 3.016 \\
\hline sign. (2-tailed) & .000 & 0.096 & 0.006 & 0.003 \\
\hline
\end{tabular}

Furthermore, hierarchical regression analysis was conducted to examine the relationship between firm's customer retention practices and its influencing factors with the control from type of retailer. As shown in Table 8, both models were found to have a significant value of 0.000 which implies that, as a whole, all the variables (Model 1 - influencing factors; Model 2- influencing factors and type of retailers) significantly influence customer retention practices with an adjusted $\mathrm{R}$ square value of $71.2 \%$ and $71.5 \%$, respectively. It implies that the said relationships are fairly strong. Significant $F$ change signifies that the inclusion of retailer's type had enhanced the relationship between influencing factors and customer retention practices though the said change is negligible (3.3\%).

In order to further assess the contribution of individual predictors towards customer retention practices, Beta value was referred. As indicated in Table 9, under Model 1, the key contributor is Factor of Customer Service while Factor of Employee was found to be least important in influencing firm's retention practices. Conversely, under Model 2, with the inclusion of retailer's type, the least important contributor is Factor of Interaction instead of Factor of Employees. As such, the inclusion of retailer's type had alleviated the importance of Factor of Employees. This could be attributed to the ability of firms in serving, satisfying and appealing to their customers over their competitors generally due to their good team of employees (Ryu et al. 2011; Sayuti, 2011).

However, it should be noted that only Factor of Switching Cost, Added Value and Customer Service has significant influence, individually, towards firm's customer retention practices with and without the impact from type of retailer. It is also worth to mention that the type of retailer is indeed a significant temperance towards the association between customer retention and its influencing factors.

Table 8: Hierarchical Regression Analysis

\begin{tabular}{|c|c|c|c|c|c|c|}
\hline \multirow[t]{2}{*}{ Model } & \multicolumn{2}{|l|}{ ANOVA } & \multirow[t]{2}{*}{$\mathbf{R}$} & \multirow{2}{*}{$\begin{array}{l}\text { R } \\
\text { Square }\end{array}$} & \multirow{2}{*}{$\begin{array}{l}\text { Adj. } \quad R \\
\text { Square }\end{array}$} & \multirow{2}{*}{$\begin{array}{l}\text { Std. Error } \\
\text { Estimate }\end{array}$} \\
\hline & $\mathbf{F}$ & Sign. & & & & \\
\hline $1^{*}$ & 165.226 & 0.000 & 0.846 & 0.716 & 0.712 & 0.4032 \\
\hline $2^{* *}$ & 143.564 & 0.000 & 0.848 & 0.719 & 0.715 & 0.4017 \\
\hline
\end{tabular}

Predictor*: (Constant), Policy \& price, Employees, Switching cost, Interaction,

\begin{tabular}{|l|l|l|l|l|}
\hline \multicolumn{5}{|c|}{ Change Statistics } \\
\hline $\begin{array}{l}\text { R Square } \\
\text { Change }\end{array}$ & $\begin{array}{l}\text { F } \\
\text { Change }\end{array}$ & df1 & df2 & $\begin{array}{l}\text { Sig. F } \\
\text { Change }\end{array}$ \\
\hline 0.716 & 165.226 & 6 & 393 & 0.000 \\
\hline 0.003 & 4.575 & 1 & 392 & 0.033 \\
\hline
\end{tabular}

Added value, Customer service

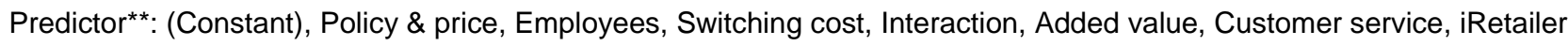

Dependent variable: Overall Customer Retention 
Table 9: Hierarchical Regression Analysis (Cont')

\begin{tabular}{|c|c|c|c|c|c|c|}
\hline \multicolumn{2}{|c|}{ Model } & \multicolumn{2}{|c|}{$\begin{array}{l}\text { Unstandardized } \\
\text { Coefficients }\end{array}$} & \multirow{3}{*}{$\begin{array}{l}\text { Standardized } \\
\text { Coefficients } \\
\text { Beta } \\
-\end{array}$} & \multirow{3}{*}{$\begin{array}{l}\mathbf{t} \\
-.149\end{array}$} & \multirow{3}{*}{$\begin{array}{l}\text { Sig. } \\
.882\end{array}$} \\
\hline & & \multirow{2}{*}{$\begin{array}{l}\text { B } \\
-.016\end{array}$} & \multirow{2}{*}{$\begin{array}{l}\text { Std. Error } \\
.109\end{array}$} & & & \\
\hline 1 & (Constant) & & & & & \\
\hline & Policy \& price & .025 & .033 & .029 & .736 & .462 \\
\hline & Employees & .014 & .044 & .015 & .318 & .750 \\
\hline & Switching cost & .186 & .023 & .256 & 8.002 & .000 \\
\hline & Added value & .166 & .034 & .184 & 4.836 & .000 \\
\hline & Customer service & .511 & .038 & .515 & 13.552 & .000 \\
\hline & Interaction & .031 & .043 & .032 & .708 & .479 \\
\hline \multirow[t]{8}{*}{2} & (Constant) & .127 & .128 & - & .995 & .320 \\
\hline & Policy \& price & .031 & .033 & .037 & .936 & .350 \\
\hline & Employees & .025 & .045 & .026 & .560 & .576 \\
\hline & Switching cost & .174 & .024 & .239 & 7.301 & .000 \\
\hline & Added value & .171 & .034 & .189 & 4.977 & .000 \\
\hline & Customer service & .507 & .038 & .511 & 13.498 & .000 \\
\hline & Interaction & .022 & .044 & .023 & .498 & .619 \\
\hline & Retailer & -.090 & .042 & -.060 & -2.139 & .033 \\
\hline
\end{tabular}

\section{Impact of Customer Retention on Firm's Non-Financial Performance}

As discussed earlier, the dimension of customer satisfaction was used as a sole measure of firm's non-financial performance in this study. The overall customer satisfaction of respondents towards the chosen retailers is at moderate level with mean value of 3.368 (STD $=0.8335$ ). Subsequently, a simple linear regression analysis was employed to examine the impact of customer retention on customer satisfaction. As shown in Table 10, about $56.9 \%$ variance in customer satisfaction is found to be significantly relying on the firm's customer retention practices. This association is considered as average though there is a significant relationship. It is worth to learn that customer satisfaction is also greatly viewed as a predictor of firm's customer retention practice (Reinartz \& Kumar, 2003; Wong, 2005) instead of as an outcome resultant from firm's retention practices (Anderson et al. 2004; Gan et al. 2006). Hence, due to such bidirectional nature, it can be cautiously concluded that customer retention is in fact not a good predictor for the dimension of customer satisfaction.

Table 10: Simple Linear Regression Analysis

\begin{tabular}{|c|c|c|c|c|c|c|c|}
\hline \multirow[t]{2}{*}{ Details* } & \multicolumn{2}{|c|}{ ANOVA } & \multirow{2}{*}{$\begin{array}{l}\text { Adjusted } \\
\text { R2 }\end{array}$} & \multirow{2}{*}{$\begin{array}{l}\text { Unstandardized } \\
\text { Beta }\end{array}$} & \multirow{2}{*}{ Beta } & \multirow{2}{*}{$\mathbf{t}$} & \multirow{2}{*}{$\mathbf{p}$} \\
\hline & $\mathbf{F}$ & $\mathbf{p}^{\star \star}$ & & & & & \\
\hline (constant) & \multirow[b]{2}{*}{528.311} & \multirow[b]{2}{*}{0.000} & \multirow[b]{2}{*}{0.569} & 0.769 & - & 6.612 & 0.000 \\
\hline $\begin{array}{l}\text { Overall customer } \\
\text { retention }\end{array}$ & & & & 0.838 & .755 & 22.985 & 0.000 \\
\hline
\end{tabular}

** Significant at 0.05 level;

* Dependent variable: Customer satisfaction 


\section{THEORETICAL AND MANAGERIAL IMPLICATIONS}

This study investigated the relationship between customer retention practice and its influencing factors. Impact of customer retention practices on the firm's non financial performance (i.e. customer satisfaction) was also explored. The findings of this study are expected to provide constructive implications for both academics and practitioners.

The research framework of this study could serve as a guideline for future researchers to further explore customer retention practices. Future researchers shall investigate other disciplines of customer retention practices such as advantages, disadvantages, barriers, to name a few. Besides, the framework also can be extended for researches within other economic sectors or business activities. In addition, findings and research framework of this study could enrich the exiting literatures on customer retention practices and retailing sector.

Based on the scrutiny of the proposed framework, it was discovered that the influencing factors could be systematically categorized into three main components namely company, customer and collaboration (i.e. 3Cs model). The component of company shall consist of top management, pricing, employees, membership and interaction; the component of customer shall consist of perceived service quality and switching cost; the component of collaboration consists of CRM and customer service. This suggests that future researchers would be able to investigate the customer retention practices from a specific component of the 3Cs model discovered in this study.

Besides, the finding of this study could be incorporated into the teaching syllabus of subjects such as retailing, service management and customer relationship management in order to enrich the learning process. Such practical knowledge would churn out good prospects for future employers.

Findings from Table 6 and 7 indicate that customers are in deed price sensitive despite being loyal and retained by firms. Price sensitivity of customers is justifiable with the availability of enormous alternatives for their purchases online and instore. This has greatly influenced the spending pattern of customers who have become bargain hunters. Hence, it is advisable for retailers to pursue a genuine pricing strategy to appeal to price conscious customers. The pricing strategy ideally should be transparent (i.e. no-bogus sale), clarity (i.e. provide accurate details of merchandises), simplicity (i.e. avoid psychological pricing) and trustable (i.e. provide accurate balances).

On one hand, the contribution of employees towards customer retention practices was discovered to be influenced by the individual retailers. Retailers should build a good base of employees in ensuring a lasting relationship with their customers. This is because employees portray the corporate image of retailers besides being the initial contact point of customers.

On the other hand, word-of-mouth and repeat purchases which are the essential components of Factor of Bonding were found to be key measures of customer retention practices. This proposes retailers to engage in activities which will influence the customers to spread positive word-of-mouth and to increase their repurchases. Retailers shall participate in corporate social responsibility oriented activities to create a positive corporate image in the eye of both existing and potential customers.

\section{LIMITATION AND RECOMMENDATION}

As this study is descriptive in nature, underlying responses of respondents were not discovered. Their responses were confined with the pre-determined options given in the research instrument. As such, it is recommended to employ a mixedmode research in the future in order to obtain the underlying responses besides describing respondents' responses in detail.

Next, this study had focused on two chosen retailers located at Klang Valley, Malaysia. This had raised concerns on the generalization of findings to the entire population. However, it is believed the said concern is eliminated with the large sample size of this study. Future researchers shall investigate retailers nationwide for a more representative finding.

Besides, findings of this study had uncovered a modest association between customer retention practices and the sole measure of firm's non-financial performance (i.e. customer satisfaction). Future researchers should incorporate more nonfinancial performance measures together with financial measures in order to apprehend the exact performance of firms resulted from their customer retention practices.

\section{ACKNOWLEDGMENT}

This project is funded by an internal research grant (IPSR/RMC/UTARRF/2012-C1/P01) obtained from Universiti Tunku Abdul Rahman, Perak, Malaysia.

\section{REFERENCES}

[1] Addai-Minkah, M. (2011). The Importance of Customer Service in the Banking Industry; The Case Of Ecobank Ghana Limited. Executive Masters of Business Administration Dissertation, Kwame Nkrumah University of Science and Technology.

[2] Al-Eisa, A. S. \& Alhemoud, A. M. (2009). Using a multiple-attribute approach for measuring customer satisfaction with retail banking services in Kuwait. International Journal of Bank Marketing, 27(4), 294-314.

[3] Anderson, E. W., Fornell, C. \& Mazvancheryl, S. K. (2004). Customer satisfaction and shareholder value. Journal of Marketing, 172-185. 
[4] Ang, L. \& Buttle, F. (2006). Customer retention management processes - a quantitative study. European Journal of Marketing, 40(1/2), 83-99.

[5] Arnold, J.T., Fang, E. \& Palamtier, W. (2011). The effects of Customer acquisition And retention orientations on a firm's radical and incremental innovation performance. Journal of Academic Marketing Science,39, 234-251.

[6] Avci, U., Madanoglu, M., \& Okumus, F. (2011). Strategic orientation and performance of tourism firms: Evidence from a developing country. Tourism Management, 32(1), 147-157.

[7] Bassey, N. E., Okon, U. E, \& Umorok, U. E. (2011). Effective customer service: a tool for client retention among stock broking firms in Nigeria. African Journal of Business Management, 5(20), 7987-7991.

[8] Baxter strategies incorporated. (2004). Customer retention strategies: a business imperative. Wellington.

[9] Bolton, R.N., Kannan, P. K. \& Bramlett, M. D. (2000). Implications of loyalty program membership and service experiences for customer retention and value. Journal of the Academy of Marketing Science, 95-108.

[10] Bowen, J. \& Chen, S. (2001). The relationship between customer loyalty and customer satisfaction. International Journal of Contemporary Hospitality Management, 13(5), 213-217.

[11] Burton, L.J. \& Mazerolle, S.M. (2011). Survey instrument validity part I: Principles of survey instrument development and validation in athletic training education research. Athletic Training Education Journal. 6 (1), 27-35.

[12] Caruana, A. (2002). Service loyalty: The effects of service quality and the mediating role of customer satisfaction. Journal of Marketing,36(7/8), 811-828.

[13] Currah \& Wrigley. N. (2004). "Networks of organizational learning and adaptation in retail tncs," Global Networks, A Journal of Transnational Affairs, 4(1), 1-23.

[14] Customer Retention Statistics. (2013, January 24). Retrieved May 07, 2013, from http://info.rdioutsourcing.com/bid/209948/Customer-Retention-Statistics.

[15] Dawes, J. 2009. "The effect of service price increases on customer retention: the moderating role of customer tenure and relationship breadth". Journal of Service Research, 11(3), 232-245.

[16] Dawkins, P. and Reichheld, F. (1990) "Customer Retention as a Competitive Weapon", Directors and Boards, 4(14).

[17] Eliwa , R. A. (2006). A study of customer loyalty and the image of the fine dining restaurant. Unpublished master's thesis, University of Helwan, Oklahoma, United State.

[18] Erdis, C. (2009). Investing customer service in selected restaurants in the Tshwane area - An exploratory study. (Master's thesis, University of South Africa, 2009).

[19] Farquhar, J.D. (2004). Customer retention in retail financial services: an employee perspective. The International Journal of Bank Marketing, 22(2), 86-99.

[20] Feinberg, R. \& Kadam, R. (2002). E-CRM web service attributes as determinants of customer satisfaction with retail web sites. International Journal of Service Industry Management. 13(5): 432-451.

[21] Fiorletta, A. (2012, April 25). Keys To Maximizing Customer Retention And Loyalty. Retrieved June 07, 2013, from http://www.retailtouchpoints.com/shopper-engagement/1531-keys-to-maximizing-customer-retentionand-loyalty.

[22] Fill, C., 2005. Marketing Communications: contexts, strategies, and applications (4thed.). Pearson Education Limited, New York.

[23] Gan, C., Cohen, D., Clemes, M., \& Chong, E. (2006). A survey of customer retention in the New Zealand banking industry. Journal of Banks and Banks System, 1(4), 83-99.

[24] George, D. \& Mallery, P. (2001). SPSS for Windows - Step by Step - A Simple Guide and Reference 10.0 Update. (3rd ed.) USA: Allyn \& Bacon.

[25] Gupta, S., Hanssens, D., Hardie, B., Kahn, W., Kumar, V., Lin, N., Ravishankar, N., \& Sriram, S. (2006). Modeling customer lifetime value. Journal of Service Research, 9(2), 139-155.

[26] Gupta, S. \& Zeithaml, V. (2006). Customer metrics and their impact on financial performance. Marketing Science, 25(6): 718-739.

[27] Gustafsson, A., Johnson, M. D. \& Roos, I. (2005). The effects of customer satisfaction, relationship commitment dimensions, and triggers on customer retention. Journal of marketing, 210-218.

[28] Haghighi, M., Dorosti, A., Rahnama, A., \& Hoseinpour, A. (2012). Evaluation of factors customer loyalty in the restaurant industry. Journal of Business Management, 6(14), 5039-5046.

[29] Hansemark, O. C., \& Albinson, M. (2004). Customer satisfaction and retention: the experiences of individual employees. Journal of Work, Economic, and Health, 14(1), 40-57.

[30] Hennig-Thurau, T. (2004). Customer orientation of service employees - its impact on customer satisfaction, commitment and retention. International Journal of Service Industry Management, 15(5), 460-478.

[31] Heung, V. C. S. \& Ngai, E. W. T. (2008). The mediating effects of perceived value and customer satisfaction on customer loyalty in the Chinese restaurant setting. Journal of Quality Assurance In Hospitality \& Tourism, 9(2), 85-107. 
[32] Inside Malaysia. (2012, July). Wholesale \& Retail. Retrieved May 19, 2013, from http://etp.pemandu.gov.my/upload/Inside\%20Investor\%20\%20Wholesale\%20and\%20Retail.pdf.

[33] Jin, N. H., Lee, S. M., \& Huffman, L. (2011). What matter experiential value in casual-dining restaurants? University of Texas Tech.

[34] Kotler, Philip, Armstrong, Gary, Saunders, John and Wong, Veronica. (1999). "Principles of Marketing" 2nd ed. Prentice Hall Europe.

[35] Kotler, P. (2005). According to Kotler: The World's Foremost Authority on Marketing AnswersYour Questions. New York: AMACOM.

[36] Kotler, P., \&Keller, K. (2006). Marketing Management. (12th eds.), Pearson, Upper Saddle River, NJ.

[37] Kumar, V., Andrew, J.P. \& Robert, P.L. (2007). How valuable is word of mouth? Harvard Business Review, 85(10), 139-146.

[38] Kwon, K. and Kim, C. (2012, January 24). Electronic Commerce Research and Applications 11. 101-116.

[39] Liao, H., \& Chuang, A. (2004). A multilevel investigation of factors influencing employee service performance and customer outcomes. Journal of Academy of Management, 47(1), 41-58.

[40] Lindsay, E. (2012, April 20). Malaysia's GDP driven mainly by services, manufacturing sectors. Retrieved May 20, 2013, from http://www.theborneopost.com/2012/04/20/malaysias-gdp-driven-mainly-by-servicesmanufacturing-sectors/\#ixzz2Y35z3Ckg.

[41] Malaysia Watch Content (2010, March 16). Malaysia industry sector. Retrieved May 17, 2013, from http://www.economywatch.com/world economy/malaysia/industry-sector-industries.html.

[42] Matsuura, T. (2004). Productivity in the Service Sector: Retail Industry. Recent Trends and Prospects for APO Member Countries. 2004 asian productivity organization. Retrieved May 2, 2013, from http://www.apotokyo.org/publications/files/rr2009 0428 retail industry.pdf

[43] Mazzarol, T., Sweeney, J. C. \& Soutar, G. N. (2007). Conceptualizing word-of-mouth activity, triggers and conditions: an exploratory study. European Journal of Marketing, 41(11/12), 1475-1494.

[44] MIDA Malaysia Investment Performance (2011). Retrieved May 21, 2013, from http://www.mida.gov.my/env3/uploads/PerformanceReport/2011/Report.pdf.

[45] MITI Weekly Bulletin (2013, February 26). Retrieved June 10, 2013, from http://www.indexmundi.com/malaysia/gdp composition by sector.html,

http://www.mida.gov.my/env3/index.php?page=policies-guidelines-and-incentives, http://www.mida.gov.my/env3/index.php?page=services-sector, \&http://myservices.miti.gov.my/web/guest/overview1.

[46] Molapo, M. E., \& Mukwada, G. (2011). The impact of customer retention strategies in the South African cellular industry: The case of the Eastern Free State. Journal of Business, Humanities and Technology, 1(2), 52-60.

[47] Mustaza, M (2012, March 19). Retail sector spurs economy. Retrieved April 15, 2013, from http://www.nst.com.my/nation/general/retail-sector-spurs-economy-1.62655\#ixzz2Y78DMgWG.

[48] Ndubisi, N. O. (2007). Relationship quality antecedents: the Malaysian retail banking perspective. International Journal of Quality \& Reliability Management, 24(8), 829-845.

[49] Omar, N. A., Musa, R. \& Nazri, M. A. (2007). Program perceived value and program satisfaction influences on store loyalty: insights from retail loyalty progam. Gadjah Mada International Journal of Business, 9(3).

[50] Oyeniyi, O., \& Joachim, A. A. (2008). Customer service in the retention of mobile phone users in Nigeria. African Journal of Business Management, 2(2), 026-031.

[51] Page, M., Pitt. L. \& Berthon, P. (1996). Analysing and reducing customer defections. Long Range Planning. 29 (6), 821-834.

[52] Polo, Y., Sese, F. J., \& Verhoef, P. C. (2011). The effect of pricing and advertising on customer retention in a liberalizing market. Journal of Interactive Marketing, 25(4), 201-214.

[53] Ranaweera, C. \& Prabhu, J. (2003). The influence of satisfaction, trust and switching barriers on customer retention in a continuous purchasing setting. International Journal of Service Industry Management, 14(4), 374-395.

[54] Rasha-Ali, E. (2006). A study of customer loyalty and the image of the fine dining restaurant. Unpublished Master's thesis, University of Helwan.

[55] Razak, M. R. A., Chong, S. C. \& Lin, B. (2007). Service quality of a local Malaysian bank: customers' expectations, perceptions, satisfaction and loyalty. International Journal of Services and Standards, 3(1), 18 38.

[56] Reichel, A. \& Haber, S. (2005). A three-sector comparison of the business performance of small tourism enterprises: An exploratory study. Tourism Management. 26, 681-690.

[57] Reichheld, F.F. \& Schefter, P. (2000). E-Loyalty: your secret weapon on the web. Harvard Business Review, 78(4), 105-113. 
[58] Reinartz, W. J. \& Kumar, V. (2003). The impact of customer relationship characteristics on profitable lifetime duration. Journal of marketing, 77-99.

[59] Roberts, K., Varki, S. \& Brodie, R. (2003), "Measuring the quality of relationship in consumer services: an empirical study", European Journal of Marketing, 37, 169-196.

[60] Ryu, K., Lee, H. R., \& Kim, W. G. (2011). The influence of the quality of the physical environment, food, and service on restaurant image, customer perceived value, customer satisfaction, and behavioural intentions. Journal of Contemporary Hospitality Management, 24(2), 200-223.

[61] Samat, N., Ramayah, T., \& Saad, N. M. (2006). TQM practices, service quality, and market orientation: some empirical evidence from a developing country. 29(11), 713-728.

[62] Sayuti, S. A. (2011). Customer satisfaction toward service quality in RFC restaurant: A case study in Kedah. 1-77.

[63] Seo, D., Ranganathan, C. \& Babad, Y. (2008). Two-level model of customer retention in the US mobile telecommunications service market. Telecommunications Policy, 32(3), 182-196.

[64] Sim, J., Mak, B., \& Jones, D. (2008). A model of customer satisfaction and retention for hotels. Journal of Quality Assurance in Hospitality \& Tourism, 7(3), 1-23.

[65] Singh, H. (2006). The importance of customer satisfaction in relation to customer loyalty and retention. Academy of Marketing Science, 60, 193-225.

[66] Star Online. (2013, June 6). Better than forecast retail sales in the first quarter. Retrieved June 10, 2013, from http://www.thestar.com.my/Business/Business- News/2013/06/06/Better-than-forecast-retail-sales-inthe-first-quarter.aspx.

[67] Stengel, G. (2003). Ten tips for measuring and improving performance. Stengel Solutions. http://www.stengelsolutions.com/tips14.htm. Accessed on 28th February 2012.

[68] Steven, A. B., Dong, Y. \& Dresner, M. (2012). Linkages between customer service, customer satisfaction and performance in the airline industry: Investigation of non-linearities and moderating effects. Transportation Research Part E: Logistics and Transportation Review, 48(4), 743-754.

[69] Tu, Y. T., Lin, S. Y., \& Chang, Y. Y. (2011). Relationships among service quality, customer satisfaction and customer loyalty in chain restaurant. Information management and business review, 3(5), 273-282.

[70] Venetis, K. A. \& Ghauri, P. N. (2004). Service quality and customer retention: building long-term relationships. Journal of Marketing, 38(11/12), 1577-1598.

[71] Vesel, P. \& Zabkar, V. (2010). Comprehension of relationship quality in the retail environment. Managing Service Quality, 20(3), 213-235.

[72] Villanueva, J. \& Hanssens, D. M. (2007). Customer equity: measurement, management and research opportunities. Foundations and Trends in Marketing, 1(1),1-95.

[73] Voon, B. H. (2011). Service environment of restaurant: findings from the youth customers. Journal of ASIAN Behavioral Studies, 1(2), 45-56.

[74] Wadongo, B. Odhuno, E., Kambona, O., \& Othuon, L. (2010). Key performance indicators in the Kenyan hospitality industry: a managerial perspective. Benchmarking: An International Journal, 17(6), 858-875.

[75] Wang, E. S. T. (2010). Impact of multiple perceived value on consumers' brand preference and purchase intention: a case of snack foods. Journal of Food Products Marketing, 16(4), 386-397.

[76] Wilkins, H. Merrilees, B. \& Herington. C. (2010). The Determinants of loyalty in hotels. Journal ofHospitality Marketing \& Management, 19, 1-21.

[77] Woo, K. \& Fock, H.K.Y (2004). Retaining and divesting customers: an exploratory study of right customers, at-risk right customers, and wrong customers. Journal of Services Marketing, 18(3), 187-197.

[78] Wong, C. B. (2005). The influence of customer satisfaction and switching costs on customer retention : a survey of retail internet banking users in Hong Kong. Unpublished doctoral dissertation, University of South Australia.

[79] Wrigley, N. \& Lowe, M. (2010, November 17). The Globalization of Trade in Retail Services. Report commissioned by the OECD Trade Policy Linkages and Services Division for the OECD Experts Meeting on Distribution Services, Paris. 1-39.

[80] Yee, R. W., Yeung, A. C. \& Edwin Cheng, T. C. (2010). An empirical study of employee loyalty, service quality and firm performance in the service industry. International Journal of Production Economics, 124(1), 109-120.

[81] Yuksel \& Yuksel (2003). Measurement of tourist satisfaction with restaurant services: A segment-based approach. Journal of Vacation Marketing, 9(1), 52-68.

[82] Yunus, N. K. Y. (2009). Justice oriented recovery strategies and customer retention in the retail banking industry in Malaysia. International Review of Business Research Papers, 5(5), 212-228. 